\title{
THE RULES OF COMPETITION WITHIN THE EUROPEAN COMMON MARKET*
}

\author{
FERNAND SpaAk ${ }^{\dagger}$ and JEAN N. JaEger $\ddagger$
}

Although this article deals with two different Treaties, concluded at different periods and for different products, it actually refers to the Common Market of one single European Community. Furthermore, the Common Market is not the simple juxtaposition or the simple addition of the national markets of Germany, Belgium, France, Italy, Luxembourg, and the Netherlands; the implementation of the European Treaties aims at the integration of these separate markets, the European Common Market being the basis of a new economic unit, the European Community.

This unity is already reflected at the institutional level in the existence of a single Court of Justice and a single Parliament for the Community. ${ }^{1}$ Furthermore, the Council of Ministers consisting of one member from each of the six Governments, is likewise a common institution of the three Communities, although the Ministers meeting for the European Economic Community (E.E.C.) or the European Coal and Steel Community (E.C.S.C.) are not the same in each case, nor are the powers conferred on the Council the same under each of the two Treaties.

The rules of competition illustrate clearly the unity of the Common Market, based as they are on the same principles of economic policy. The fact that, in practice, these rules are applied by different institutions-for the E.C.S.C., High Authority, and for the E.E.C., the national authorities, the Commission, and the Council of Ministers-cannot disrupt this unity because, on the one hand, the parliamentary control and, accordingly, the political impulse lie within the jurisdiction of one and the same Parliamentary Assembly; and because, on the other hand, the

- The writers have, over the last few years, been intimately associated with the implementation of the rules of competition within the European Common Market. Their professional work has enabled them to observe very closely the gradual development of a corpus of legal precedents, administrative and juridical. To avoid the risk of their account being regarded as an official interpretation and to enable them to express their opinion as freely as possible, they have chosen to write this article entirely on their personal responsibility.

+Docteur en droit 1948, University of Brussels; B.A. 1950, Cambridge University. Director, Cartels and Concentrations Division, High Authority of the European Coal and Steel Community; DirectorGeneral, Supply Agency, European Atomic Energy Community. Secretary, Economic Division, High Authority of the European Coal and Steel Community, x952-54; Executive Assistant to the President, 1954-58; Deputy Director, Cartels and Concentrations Division, x958-60.

$\ddagger$ Ingénieur Commercial 195x, University of Brussels. Principal Officer, Cartels and Concentrations Division, High Authority of the European Coal and Steel Community.

${ }^{2}$ Although the Treaty instituting Euratom provides for the establishment of a Common Market, it contains no rules of competition applicable to the enterprises, and this for the following reasons:

(I) The nuclear industry is only being created, and this creation requires a very close cooperation from the scientific, industrial, and financial point of view.

(2) The supply of fissionable materials, under equal conditions, is assured by the supply agency as directed by the Euratom Commission.

(3) The use of the materials is under control; Euratom assures the coordination of research and promotes the creation of common enterprises. 
jurisprudence must, of necessity, be unified by the judgments of a single Court of Justice.

In order to demonstrate the unity of the Common Market more effectively, the writers will describe the rules of competition of the two Treaties not separately, but side by side, thereby underlining their identity and the points on which, for technical and economic reasons, a differentiation has, nevertheless, been unavoidable.

In contrast to the national laws on competition, the rules of competition of the Common Market are directed at the behavior of the States as well as at the behavior of the enterprises. The intention of the authors of the Treaty having been to create a genuine Common Market, it would, indeed, have been vain to subject enterprises to rules while allowing state monopolies or laws and government measuressuch as subsidies or restrictions on trade-to persist. The Treaties provide for the amendment or prohibition of government measures which prevent the integration of the national markets as effectively as practices of the enterprises. In order not to exceed the scope of this article, however, the writers will confine themselves to the rules of competition as they apply to the enterprises.

The Principles of Competition within the Common Market

There is a fundamental difference between the basic principles of the rules of competition instituted under national laws and those laid down in a treaty establishing a common market. National laws are laid down after the national market has been in existence for some considerable time. National laws have exclusively the purpose of protecting the consumer and the general interest. They are founded either upon economic principles or upon ethical grounds of equality and liberty, in line with the aspirations and the way of life of the inhabitants of the country. Competition thus becomes an end in itself, and the laws serve to attain this end.

Where it is proposed to introduce a common market, however, the process is completely reversed. Rules of competition are laid down in advance-i.e., before the common market has come into being. To introduce a common market among several countries, it is not enough to abolish customs duties and quotas, to harmonize economic and currency policies, and to achieve a harmonized transport policy, if enterprises continue to be confined within their former national borders, out of tradition, habit, or simply intertia. There can obviously be no question of compelling the enterprises to act against their own will, but it is necessary to lay down rules of behavior that will allow enterprises and consumers to respond freely and on equal terms to the new economic incentives offered by the common market. These rules are designed to make it impossible to circumvent the measures establishing the common market and, in particular, to restore impediments to trade by practices restricting or distorting competition.

With the establishment of a common market as the objective, competition is, therefore, not an end in itself, but one of the main instruments of an economic policy 
aiming at the integration of the markets. Competition has been chosen as the motive force of the economic revolution that is to promote the interpenetration of several national economies, prisoners for centuries of their different structures, different traditions and habits, and merge them in a new economic entity, the European Common Market.

The main consequence of the subordination of competition to the purpose of establishing a common market is that the rules of the Treaties do not aim at introducing or maintaining any kind of competition. It is not a question of competition at any price, but of creating the degree of competition required to attain the objectives of the Treaties. Excessive competition leading to fundamental disequilibria or to disturbances in the economy of the Member States, especially in the social field, must be prevented.

This limitation placed on the concept of competition, which deprives it of its dogmatic character, is defined in article two of both Treaties setting forth the objectives to be attained. According to the E.C.S.C. Treaty, the Community must "progressively establish conditions which will in themselves assure the most rational distribution of production at the highest possible level of productivity, while safeguarding the continuity of employment and avoiding the creation of fundamental and persistent disturbances in the economies of the member States." Under the E.E.C. Treaty, the aim is "to promote throughout the Community a harmonious development of economic activities, an accelerated raising of the standard of living and closer relations between its Member States."

Thus, while the conception of competition is similar in both cases, the formulation is not identical in the two Treaties. It is, therefore, necessary to pinpoint the differences existing between the rules of competition in the two Treaties and to explain why these rules are more detailed, more precise, and more extensive in the E.C.S.C. Treaty than they are in the E.E.C. Treaty.

\section{II}

The Fundamental Differences between the Two Treattes

The outstanding difference, which logically involves all the other differentiations, stems from the fact that the E.C.S.C. Treaty establishes a Community for two basic industries only, coal and steel, while the E.E.C. Treaty establishes a Community comprising all the other sectors of economic activity.

Though limited to two industries, the economic integration provided for in the E.C.S.C. Treaty affects the basic sector of the economy. In its endeavor to create, by the integration of these two industries, at the European level a common basis for industrial expansion and further economic integration, the E.C.S.C. establishes a "pool" of coal and steel production. It is the pooling of production into a single whole that explains why the Treaty gives the High Authority definite powers in the field of production, investment, and prices.

This notion of "pool" of production could no longer apply when it came to the 
integration of the entire economy of the six countries. It was no longer a question of partial integration, limited to basic industries. In fact, it would not have been possible to transfer to an executive organ such wide powers over the whole economy of the six countries while leaving to the Governments of the States the political responsibility involved. The political unification of Europe has not as yet reached the stage where full political responsibility for economic policy can be vested in a single European Executive.

This difference explains the wording of the above-mentioned passage of article two of the E.C.S.C. Treaty, "the most rational distribution of production," which does not figure in the corresponding article of the E.E.C. Treaty.

The notion of a "pool" also explains why article three of the E.C.S.C. Treaty assigns to the institutions certain tasks that are not equally clearly defined in the E.E.C. Treaty. These tasks are worth quoting, since they show the scope and limitations of competition under the E.C.S.C. Treaty. According to this article, the institutions of the Community shall:

a) ensure that the common market is regularly supplied, while taking into account the needs of third countries;

b) assure to all consumers in comparable positions within the common market equal access to the sources of production;

c) seek the establishment of the lowest possible prices without involving any corresponding rise either in the prices charged by the same enterprises in other transactions or in the price-level as a whole in another period, while at the same time permitting necessary amortization and providing the possibility of normal returns on invested capital;

d) ensure that conditions are maintained which will encourage enterprises to expand and improve their ability to produce and to promote a policy of rational development of national resources, while avoiding undue exhaustion of such resources;

e) promote the improvement of the living and working conditions of the labor force in each of the industries under its jurisdiction so as to harmonize those conditions in an upward direction;

f) foster the development of international trade and ensure that equitable limits are observed in prices charged in foreign markets;

g) promote the regular expansion and the modernization of production as well as the improvement of quality, under conditions which preclude any protection against competing industries except where justified by illegitimate action on the part of such industries or in their favor.

If these tasks were carried out separately and independently of one another, conflicting results would be produced. The institutions must, therefore, do their utmost to combine them in order to achieve in the Member States the highest possible level of employment, the highest rate of economic expansion, and the highest standard of living. Therein lies the scope of their economic policy. The need for this constant conciliation of apparently contradictory objectives shows that no one of them can be regarded as sufficient by itself. Therefore, competition among enterprises is not a dogma in the Treaty. It is not to be introduced for its own sake.

For instance, to ensure the accomplishment of the tasks set forth in article three 
of the E.C.S.C. Treaty, the institutions are empowered, in exceptional circumstances of "manifest crisis" or shortage, to fix maximum or minimum prices, to institute financial arrangements, and to fix production quotas by countries and by enterprises.

It can thus be seen that the institutions of the Community can reduce, and even abolish, competition in serious circumstances and for definite periods. The intention has been to create a solidarity within the Community, freeing the enterprises from the major risks of competition, which would endanger the welfare of the workers and the very existence of the Community.

In return, contrary to certain national laws that enable the enterprises to conclude cartel agreements in times of serious cyclical or structural recession, the E.C.S.C. Treaty does not allow the enterprises themselves to restrict competition simply for the purpose of coping with such situations.

In the E.E.C. Treaty, apart from the quoted passage of article two, the fundamental provisions do not stipulate more detailed limits to the principles of competition. As we shall see, however, the rules of competition as laid down in that Treaty contain yet another limitation that does not exist in the E.C.S.C. Treaty: restrictions on competition are prohibited only in so far as they affect trade between the Member States.

This difference is likewise explained by the different nature of the economic activities that fall under the two Treaties. In the heavy industries of coal and steel, where the great majority of the enterprises are located within the triangle formed by the Ruhr, Lorraine, Northern France and Belgium, practically any action restricting competition directly or indirectly affects the trade between Member States. This explains why the rules of competition are more extensive in the E.C.S.C. Treaty than they are in the E.E.C. Treaty. On the other hand, numerous practices or actions restricting competition in the other sectors of economic activity have a purely local effect, without in any way affecting the establishment or the functioning of the Common Market. In both Treaties, the principle remains the same: they regulate competition only in so far as this is necessary to the Common Market.

Like the E.C.S.C. Treaty, the E.E.C. Treaty does not provide for the possibility of coping with situations of glut or shortage by means of agreements between enterprises. The Governments have retained the requisite powers in regard to prices, while the Treaty embodies safeguards for dealing with exceptional economic or financial difficulties. ${ }^{2}$

Another major consequence of this difference between partial integration based on the pooling of productions and a broader integration with no such pooling, is the different allocation of powers among the institutions responsible for the implementation of the rules of competition. In the E.C.S.C. Treaty, the High Authority alone has the requisite executive power. Under the E.E.C. Treaty, which is more concerned

\footnotetext{
2 The Treaty provides for permanent action designed to produce a common economic policy. Precautionary measures and government action cannot, therefore, go beyond what is strictly necessary and must be confined to the needs of the Community in line with the procedures laid down in the Treaty.
} 
with the framing of a common economic policy for the entire economy of the six countries, the executive power is normally shared by the Commission and the Council of Ministers; but in regard to matters concerning competition, several other bodies also have jurisdiction, as, for instance, the national authorities ${ }^{3}$ and the Court of Justice (whose powers in this sphere remain to be defined). The rules of competition of the E.E.C. Treaty cover restrictions on competition only in so far as they affect trade between Member States. The Governments have, however, retained the power to regulate competition within their respective territories. Conflicts of law between the rules of the Treaty and the national legislation might occur. For this reason, and to ensure a nondiscriminatory application of the rules throughout the Community, the Treaty provides for close collaboration between the national and supranational authorities in matters concerning competition.

III

\section{The Fundamental Rules of Competition}

A distinction has to be made in both Treaties between the fundamental articles setting forth the principles and representing, as it were, the Constitution of the Community, and the other articles, which are nothing more than the development and codification of the principles laid down in the fundamental articles.

The fundamental rules of competition are laid down very clearly in article four of the E.C.S.C. Treaty, which says:

The following are recognized to be incompatible with the Common Market for coal and steel, and are, therefore, abolished and prohibited within the Community in the manner set forth by this Treaty:

....

b) by measures or practices discriminating among producers, among buyers and among consumers, especially as concerns prices, delivery terms and transport rates, as well as measures or practices which hamper the buyer in the free choice of his supplier; -...

d) restrictive practices tending towards the division or the exploitation of the markets.

Article five of the E.C.S.C. Treaty lists the means the Community is to employ in the execution of its tasks and specifies that it shall "assure the establishment, the maintenance and the observance of normal conditions of competition."

In the E.E.C. Treaty, the principles underlying the rules of competition are much less elaborate. According to article $3(f)$, the activities of the Community shall include "the establishment of a system ensuring that competition shall not be distorted in the common market."

\footnotetext{
${ }^{8}$ The authority of the national authorities is provided for by the E.E.C. Treaty only until the rules that shall be laid down on the basis of art. 87 come into force. The question as to whether and how far the national authorities shall keep this authority has been left open in the E.E.C. Treaty, although it is rather certain that a centralization of the powers has been anticipated.

'Independently of the coordination needed in regard to the application of the rules of competition of the Treaty, harmonization of national laws may be arrived at unider art. roo of the E.E.C. Treaty, should this prove necessary to the establishment or functioning of the Common Market. See Grisoli, The Impact of the European Economic Community on the Movement of the Unification of Law, supra, at 418.
} 
All the rules of competition of both Treaties are based on these principles. They are grouped here in four categories, according to the type of conduct they regulatenamely, (I) discrimination, unfair competition, and prices; (2) cartels; (3) concentrations; and (4) abuses of power.

\section{A. Discrimination, Unfair Competition, and Prices}

\section{Discrimination}

For the establishment and the functioning of a common market, the notion of discrimination is of much greater importance than it is in connection with a law designed to safeguard competition in one country only. There are two aspects to this notion. First, the aspect of restraint of competition, which can be found in certain laws, more especially in the legislation of the United States. Secondly, there is a more general and more important aspect that superimposes itself on the first: equal treatment of all consumers whatever their nationalities.

For the Common Market to develop into a new economic unit, it is necessary that differences in nationality should be disregarded and should no longer involve different treatment in industrial or commercial activities. The principle of nondiscrimination on these lines is important. Regardless of the effect this principle may have on competition, national prejudices and habits, deep-rooted for centuries in the different countries, must be overcome so as to enable everyone to enjoy on an equal footing the advantages of the new Common Market.

From this angle, the rule of nondiscrimination is no longer a rule of competition, but an absolute principle of equality, by which the enterprises as well as the Governments must be compelled to abide.

This dual conception of discrimination in a common market established between six different countries is clearly underlined in the E.E.C. Treaty. Article seven prohibits "any discrimination on the grounds of nationality." But article seven is not a rule of competition. It is one of the fundamental articles in the first part of the Treaty, entitled "Principles." Nondiscrimination on grounds of nationality is, therefore, a constitutional principle that applies to the Member States and to the institutions of the Community as much as it does to the enterprises. ${ }^{5}$

Independently of and over this general prohibition of discrimination on grounds of nationality, the prohibition of discrimination also figures in the rules of competition. In so far as the trade between the Member States is affected, the E.E.C. Treaty prohibits discrimination only if it is the result of an agreement or a concerted practice

"As regards the E.C.S.C. Treaty, the judgments of the Court of Justice have underlined the fact that the High Authority is required to comply with the fundamental articles of the Treaty (arts. 2-5), including the principle of nondiscrimination. $C$. Gouvernement de la République Française v. Haute Autorité, Cour de Justice de la C.E.C.A., Dec. No. I-54, I Recueil DE LA JuRISpRudence de la Cour I3 (1954-55) [hereinafter cited as REc]; Groupement des Industries Sidérurgiques Luxembourgeoises v. Haute Autorité, Cour de Justice de la C.E.C.A., Dec. No. 7-54, 2 id. 53 (I955-56); Groupement des Hauts-Fourneaux et Aciéries Belges v. Haute Autorité, Cour de Justice de la C.E.C.A., Dec. No. 8-57, 4 id. $230(1957-58)$. 
between enterprises ${ }^{b}$ or if it is caused by an enterprise occupying a dominant position in the market.?

The E.E.C. Treaty thus does not contain a rule of competition amounting to a general prohibition of discriminatory practices by individual enterprises. It is not opposed to differentiations in prices and conditions of sale.

The position is quite different under the E.C.S.C. Treaty. No distinction is made between the general prohibition of discrimination on grounds of nationality (which should be a superior principle independent of the rules of competition) and the necessity of prohibiting discriminations where these affect competition. The confusion between these two types of discrimination, plus the fact that the nondiscrimination rule has been linked with those concerning unfair competition and prices, have prompted a strict general prohibition that has since proved an obstacle to the establishment of the type of competition envisaged by the Treaty.

In chapter five, containing provisions on prices, article sixty of the E.C.S.C. Treaty develops the principle of nondiscrimination introduced by article four, as follows:

Pricing practices contrary to the provisions of Articles 2, 3 and 4 are prohibited, and in particular:

....

- discriminatory practices involving within the common market the application by a seller of unequal conditions to comparable transactions, especially according to the nationality of the buyer.

This shows how the two types of discrimination have been merged. Although it defines the notion of discrimination, this article does not enumerate discriminatory practices. This is left to the High Authority, which, after consulting the Consultative Committee and the Council, can define these practices. We shall see what use has been made of this power and how the prohibition of the discriminations is enforced when we come to deal with the rules on prices.

It should be noted that prohibition of discrimination is also provided for in article seventy of the E.C.S.C. Treaty, concerning the transport of goods between the territories of the Community countries. This article deals with discriminations according to the country of origin or destination of the goods so transported. Similar provisions concerning transport are contained in article seventy-four of the E.E.C. Treaty.

\section{Unfair competition}

Apart from the prohibition of agreements imposing tying-clauses in business transactions, ${ }^{8}$ and the prohibition of dumping practices, ${ }^{0}$ which the Commission can bring to an end by issuing recommendations to the parties concerned or by authorizing the injured Member State to take protective measures, the E.E.C. Treaty does not lay down any specific rule concerning unfair competitive practices.

${ }^{\circ}$ E.E.C. Treaty art. 85.

${ }^{7}$ Id. art. 86.

${ }^{9} I d$. art. $85(x)$ e.

Id. art. 91. 
In the E.C.S.C. Treaty, article sixty, concerning prices and discriminations, prohibits unfair competitive practices. As an example of unfair practice, this article mentions purely temporary or purely local price reductions, the purpose of which is to acquire a monopoly within the Common Market. These practices, however, are not defined, this being left, as in the case of discriminatory practices, to the High Authority.

\section{Prices}

The E.E.C. Treaty does not lay down any regulations concerning prices when fixed by enterprises individually. Only where prices are fixed by means of agreements or by concerted practices, or where such price-fixing constitutes an abuse of a dominant position, do the provisions of article eighty-five and eighty-six restrict the freedom of action of the enterprises in so far as trade between the Member States may be affected by their action.

In the E.C.S.C. Treaty as it has been seen, both the prohibition of discriminations and of unfair competitive practices introduce an element of rigidity into pricing. This rigidity is further increased by the rules of publicity laid down in article $60(2)$.

While allowing a basing point for establishing a choice of prices, article $60(2)$ makes it obligatory for all enterprises to publish, to the extent and in the form prescribed by the High Authority, their price-lists and conditions of sale.

The main concern in laying down these rules was not so much to ensure competition as such, as to secure perfect market transparency in order to assure equal access to the sources of production to all consumers, ${ }^{\mathbf{1 0}}$ in particular to consumers of a nationality different from that of the producer; and to make any discrimination and unfair practices, if not impossible, at least very difficult. This absolute principle of nondiscrimination, a vital necessity for abolishing differences of nationality in a common market, has thus been incorporated into the rules of competition.

The choice of basing points was introduced to make allowance for those enterprises that have insufficient local sales possibilities on account of the smallness of their national market. It was thought that the basing points would make it easier for them to penetrate into the Common Market. Probably it was also felt that in view of the fact that most of the enterprises in the Community are concentrated within a relatively small area, a system of basing points did not present any major drawback.

The prices are made less rigid by the fact that article sixty allows enterprises to align their quotations, by means of reductions, with those of competing enterprises whose price-list is established on another basing point. This alignment may be only partial where the discount allowed is smaller than the price-difference between the two competitors, but it cannot be greater than this difference. Consequently, price-competition can only take place either by changing the price-list or by alignment with pricies based on another basing point. ${ }^{11}$ The High Authority, however, can

\footnotetext{
${ }^{10}$ E.C.S.C. Treaty art. 3 b.

${ }^{11}$ A communication, published in [r954] Journal Officiel de la CommunautE Europtenne du Charbon ET de L'Acier 22 [hereinafter referred to as Journal. Officiel], sets out the details of the rules with which the enterprise must comply in regard to price-alignment for sales of steel.
} 
limit or prohibit these alignment practices when this proves necessary in order to avoid disturbances or disequilibria within the market.

Furthermore, the enterprises can align their prices with quotations from enterprises outside the Community. In this case, too, the High Authority, to which such alignments must be reported may limit or prohibit these in case of abuse.

This set of rules has produced a definite pattern of competition. Owing to the close propinquity of the various plants, and because the enterprises are obliged to adhere to their published prices and conditions of sale, the result of these rules has been a rather limited number of basing points, the enterprises in a particular area having generally chosen the same basing point, and a standardization of prices by areas of the Common Market. Competition by alignment discounts, therefore, is essentially competition between industries of different areas, though it also has certain effects on competition among enterprises within the same area.

Generally speaking, the E.C.S.C. Treaty is applicable only to producers, except in the case of the rules concerning agreements and concentrations that also apply to dealers. Notwithstanding this principle, all the provisions of article sixty can be extended to the dealers, although only indirectly. Under article sixty-three, the High Authority may require that the producers oblige their dealers to respect their published price-lists and that the producers be held responsible for any violation. Furthermore, the High Authority may temporarily deprive the producers of the right to do business with an offending dealer.

This extension was necessary in order to prevent producers from getting around the provisions of article sixty through their direct dealers. The High Authority may also, to the same end, address to the Member States any recommendation necessary to ensure that the dealers comply with the rules of nondiscrimination and the prohibition of unfair competitive practices.

Fines of up to twice the value of the irregular sales may be imposed by the High Authority on the enterprises that do not comply with the rules of article sixty or with decisions taken in implementation of this article. The decisions of the High Authority imposing pecuniary sanctions are legally enforceable throughout the whole territory of the Common Market.

In its Decisions Nos. $4 / 53$ and $3 \mathrm{I} / 53,{ }^{12}$ the High Authority had laid down very detailed rules concerning the publication of price-schedules and conditions of sale. According to these rules, only the prices and conditions in respect of socalled unusual transactions-i.e., isolated transactions of a special nature-need not be published. Apart from this, any price difference, such as quantity discounts, fidelity rebates or trade discounts, must be shown in the price-lists. The High Authority has made it obligatory for the producers, by these decisions, to compel their direct dealers to respect the prices and conditions published in the schedules.

Side by side with the rules on publicity, the High Authority introduced certain measures concerning alignments and defined the practices prohibited under article 60(I) of the E.C.S.C. Treaty.

\footnotetext{
${ }^{23}$ [I953] JOURNAI OfFicIeL 3 , III.
} 
Since the structure of the coal-mining industry and, in particular, the marked? differences between the production costs of the different coalfields did not allow a competition by alignment without serious disturbances-especially of social naturethe High Authority, by its Decision No. $3 / 53,{ }^{13}$ in accordance with section twentyfour of the Convention containing the Transitional Provisions, prohibited price alignments in respect of sales of coal during the transitional period, except wherespecially authorized by it. Subsequently, the High Authority allowed the introduction of zone prices.

By Decision No. $30 / 53,{ }^{14}$ the High Authority gave a definition of the forbidden discriminatory practices, the basic definition being that any price difference that is: not published in the price-schedule constitutes a discrimination. Both rules-that of publicity and that of nondiscrimination-are thus combined.

This set of rules very soon proved to be too rigid, as it left no flexibility of action: to the enterprises and impeded the play of competition within the Common Market.. This excessive rigidity made itself felt first in the steel market, and much later, raised problems, difficult to solve, in the coal market.

The High Authority first made its basic definition of discriminatory practices. more flexible by separating the rule of nondiscrimination from that of publicity.According to Decision No. $1 / 54,{ }^{15}$ a deviation from the price-list constitutes a discrimination only where the seller cannot prove that the transaction in question falls. outside the conditions specified in the price-list or where the seller cannot prove that: the price-differences granted are extended equally to all comparable transactions. This greater flexibility does not affect the obligation to publish all price-differences. for comparable transactions.

At the same time, the High Authority sought to give more latitude for pricevariations, in order to facilitate a speedier and more flexible adaptation to the prevail-ing market situation: it amended the publicity rules in respect of the prices of steel products. Under Decision No. $2 / 54{ }^{16}$ the enterprises were no longer required to. publish price differences up and down not exceeding an average of 2.5 per cent of thepublished price, these deviations being permitted only for a period not exceeding. sixty days. Only where the average price difference exceeded 2.5 per cent, or where. these differences were granted over a period exceeding two months, did the enterprise concerned have to alter its price-schedule in order to keep published prices in. line with the prices actually charged in the market.

The enterprises made extensive use of this latitude. The French Government, however, appealed against Decision No. 2/54 before the Court of Justice, as it considered that such relaxation of the publicity rules was incompatible with the

\footnotetext{
${ }^{13}$ Id. at 3 .

16 Id. at 109.

15 [1954] JouRnal OFFICIEL, $21 \%$.

${ }^{10}$ Id. at 218 .
} 
Treaty. The Court found for the French Government, and Decision No. 2/54 was reversed. ${ }^{17}$

In 1958 , the situation in the coal market deteriorated, since the enterprises were no longer able to sell their entire production. Owing to the differences in the structure of the various coal fields of the Community and between production costs, the price of coal was not the same throughout the whole Common Market. This situation was liable to cause serious disturbances: enterprises with low production costs, finding their sales within their own particular area diminishing, tended to step up their sales to the areas where prices were higher, thereby increasing the difficulties in the areas already seriously affected by the shrinkage of the markets. To avoid these difficulties, the High Authority limited the right of alignment with the lowest competing prices to a certain proportion of the tonnage sold within the area in question during a given reference period, ${ }^{18}$ alignment thus becoming a defensive measure.

These alignment rules regulate price competition among the producers of the Community, and the last paragraph of article 6o(2) of the E.C.S.C. Treaty, which permits alignments with quotations from producers outside the Community, makes it possible to meet competition from imported coal. It does not, however, regulate competition with the other sources of energy, and in particular with fuel oil. In the structural crisis through which the European coal industry is now going, competition from fuel oil is growing. The E.C.S.C. Treaty does not contain any rule governing competition with substitute products, and the E.E.C. Treaty, which covers fuel oil, contains no rules governing prices.

The difference between the two Treaties in regard to rules of competition thus creates a difficult situation, owing to the fact that the competing products and producers are subject to different régimes-almost complete freedom for fuel oil and very strict regulations for coal.

In conjunction with the coordination of the energy policies of the Community, endeavors are being made to deal with this problem. These endeavors may follow one of two main lines: either to apply to fuel oil the pricing system of the E.C.S.C. Treaty, or to make these rules less rigid, to begin with, and extend them to fuel oil later on. The first course is rather difficult, owing to the size and the international character of the oil companies. The alternative course comes up against legal and technical difficulties.

The principal legal obstacle is the position taken by the Court, which has already once opposed the relaxation of the publicity rules and, in a more recent case, found that the main purpose of price publicity is to attain "the fundamental objectives of the Treaty."

The technical difficulties stem largely from the limits imposed by the E.C.S.C. Treaty on the "right of information and investigation" of the institutions. The criticism expressed in regard to the rigidity of certain rules of competiton of the

${ }^{17}$ Cf. Gouvernement de la République Française v. Haute Autorité, Cour de Justice de la C.E.C.A., Dec. No. I-54, I REc. 13 (1954-55).

${ }^{18} \mathrm{Cf}$. High Authority decision No. 3-58, [1958] Jourarar. Ofprcinr 157. 
Treaty generally overlooks this aspect. The scope of this right is of paramount importance for the efficient implementation of the rules of competition within the European Common Market and should be examined before we go on to deal with agreements.

a. The right of information and the rules of competition. The broader the scope of the right of information and investigation of the authority responsible for the implementation of the rules of competition, the more flexible these rules can be made without loss of efficacy.

This may be regarded as going too far, since the essential thing is to deal with the outstanding violations that are most harmful to competition. It must be remembered that there is a great difference between the national administrative authorities and the institutions of the Community. In most cases, as in the United States, the national authorities can select the cases to be dealt with, as they may deem advisable. This freedom of action is enhanced by the fact that national authorities are not compelled to take a definite position in regard to all complaints. The freedom of choice is more restricted for the institutions of the Community. Political sensitivity in a Community that is still young requires that the institutions take great care and avoid being accused of discriminations according to nationality in selecting only the most important cases. Therefore, the institutions have to examine all complaints, even those of minor importance. According to the E.C.S.C. Treaty, when an enterprise makes a complaint and this complaint is not dealt with by a decision of the High Authority, an appeal may be lodged before the Court, in accordance with article thirty-five of the Treaty, against the tacit negative decision. A similar provision also exists in article I75 of the E.E.C. Treaty. Consequently, the institutions of the Community can be obliged to take action according to the principle of legality, to the detriment of the principle of opportunity.

Article forty-seven of the E.C.S.C. Treaty forms the basis of the High Authority's right of information and investigation. This right is very extensive, and the High Authority may impose fines and daily penalty payments upon those who refuse to supply information or knowingly furnish false information. The High Authority may proceed with the most extensive investigations. Its officials enjoy, according to article eighy-six, the same rights and powers as are granted by the national laws to officials of the member countries' own tax services.

These powers, however, are often inadequate. In the first place, article five of the E.C.S.C. Treaty requires of the institutions of the Community that they carry out their activities "with as small an administrative machinery as possible." The administrative means are thus too limited for carrying out extensive investigation. Secondly, the powers of control may be exercised only on enterprises producing or selling products covered by the Treaty. This limitation, a direct consequence of partial integration, is a great weakness of the Treaty.

The effects of this limitation are felt most noticeably when ensuring compliance with the rules of competition concerning prices and nondiscrimination. Checking 
which cannot be carried farther than the first, or even the second stage in distribution -i.e., which cannot be followed up through all stages including the end-consumerwould have been ineffectual, unless the rules were such as to simplify these checks. "Therefore rules and published price-lists were to be rigid.

This underlines the technical difficulty referred to earlier as regards any relaxation of the rules of competition. If the publicity-requirements were relaxed and the concept of discrimination broadened, abuses would be all the more difficult to check.

In spite of the fact that article $6_{5}(3)$ of the E.C.S.C. Treaty empowers the High Authority, in accordance with article forty-seven, to "obtain any information necessary, either by a special request addressed to the interested parties or by a general regulation for that purpose," the limitation of the power of investigation may also prove an obstacle to the implementation of the rules concerning agreements, since this power does not extend to natural persons, enterprises, and associations not subject to the E.C.S.C. Treaty.

For the implementation of the rules of article sixty-six of the E.C.S.C. Treaty regarding concentrations, the High Authority's right to obtain information is, however, much more extensive, since paragraph four of this article extends it without restriction to all natural and legal persons. This extension was indispensable, owing to the fact that a concentration between enterprises can be effected by persons, with the enterprises themselves taking only a passive part in the operation. In its Decision No. $26 / 54{ }^{19}$ the High Authority has defined the type of information any natural or legal person who has acquired or regrouped the rights or assets of Community enterprises must automatically communicate to the High Authority.

Nevertheless, difficulties still arise, since the High Authority has no means of obtaining, from consumer enterprises, information often necessary to the assessment of a vertical concentration.

In the E.E.C. Treaty, the right of information of the institutions is not yet defined. Under article eighty-seven of the E.E.C. Treaty, the Council must, on the proposal of the Commission, lay down "any appropriate regulations or directives with a view to the application of the principles set out in Articles 85 and 86." Paragraph two of this article specifies that the particulars for the application of this article must be determined by "taking due account of the need, on the one hand, of ensuring effective supervision and, on the other hand, of simplifying administrative control to the greatest possible extent." This constitutes a first restriction on the right of information.

Even before the regulations defining the powers and competences of the institutions are laid down, the Commission has a right of information by virtue of article eightynine of the E.E.C. Treaty, which provides that "it shall, at the request of a member State or ex officio, investigate ... any alleged infringement ... [of the rules of Articles 85 and 86]." Such investigations must, however, be carried out "in conjunction with the competent authorities of the member States, which shall lend it

${ }^{10}$ [r954] Journal OfFiciel 350. 
their assistance ..." According to the meaning given, in practice, to the wording "in conjunction with ...,", the powers and means of action of the Commission will be either considerable or, on the contrary, restricted.

It is obvious that within this very vast and complex sphere of the over-all economy of the six countries of the Community, the Commission cannot, by itself, have the means of investigation required for the implementation of the rules of competition. It is desirable-indeed, essential-that it should be able to rely on the cooperation of the national administrations. This need is all the greater because, for as long as the regulations referred to in article eighty-seven of the E.E.C. Treaty have not been laid down, the Commission has no means of compelling the enterprises to supply information. The national authorities, however, have these powers and, moreover, have an intimate knowledge of the economic sectors involved.

This cooperation must, however, take the form of coordination, not subordination. The Commission must retain its independence and its own powers. It must be in a position to deal with the enterprises directly "in conjunction with the national authorities," but the latter must not have the possibility of shielding the enterprises from the Commission. Where checks prove necessary, the Commission must have the right of taking an active part in the investigations. It should, for instance, not be up to national authorities alone to decide as to the nature and scope of information required by the Commission, and still less so, should they be able to withhold such information from the Commission on grounds of trade secrecy.

The cooperation to be established between the Commission and the national authorities must be the crucible in which a genuine common policy concerning competition in the European Common Market will gradually evolve. But this indispensable cooperation must not be allowed to provide grounds for depriving the Commission of the right of information and direct action. The independence and the powers of the Commission are important not only from the psychological point of view-producers and dealers must be made aware of the existence of a Community with its own institutions-but also to ensure that the Commission will be in position to act as an impartial arbitrator in the competitive system created by the Treaty.

Technical reasons also have to be taken into consideration. Agreements affecting trade between Member States most directly are those that are concluded between enterprises of different countries. Where investigations have to be carried out in different countries, only direct action by the Commission, in cooperation with the national authorities, can ensure a uniform procedure and a homogeneous implementation of the rules in all the countries involved. Besides, if the Commission were deprived of the right of initiative and of its powers of investigation, it would have to rely entirely on the national authorities for detecting agreements and practices contrary to the rules of competition of the Treaty. Yet, only the institutions of the Community will have the required over-all view of the Common Market to judge whether an agreement does or does not restrict trade between Member States. Thus, if it were left exclusively to the national authorities to uncover 
violations of the rules, these might easily be implemented in different ways in the different Community countries, and imperfectly so.

\section{B. Cartels}

A perfect parallelism exists between articles sixty-five of the E.C.S.C. Treaty and eighty-five of the E.E.C. Treaty concerning cartels. The word "cartel" does not figure in either of these articles. Both prohibit "all agreements among enterprises, all decisions of associations of enterprises and all concerted practices" that, in the E.C.S.C. Treaty, would tend "directly or indirectly, to prevent, restrict or distort the normal operation of competition," and, in the E.E.C. Treaty, "are likely to affect trade between the member States, and which have as their object or result the prevention, restriction or distortion of competition within the Common Market."

The principle of economic policy is the same in both Treaties, but the differences in nature, number, and importance of the respective economic sectors have been taken into account.

In both Treaties, the general principle of prohibition is followed by a nonexhaustive enumeration of instances of prohibited agreements: price fixing (since it has no rules concerning individually fixed prices, the E.E.C. Treaty is more precise: direct or indirect fixing of purchase or selling prices or of any other trading conditions); limitation or control of production, technical development, or investment (the E.E.C. Treaty adds the limitation or control of the markets); and marketsharing or the sharing of the sources of supply (the E.C.S.C. Treaty adds the sharing of products and customers).

To this list, the E.E.C. Treaty, which contains no other specific rules on discrimination, adds two types of cartel-those establishing discriminations and those establishing unfair practices in the form of tying-clauses.

In both Treaties, the prohibited agreements are null and void. ${ }^{20}$

Like any legislation on agreements, the Treaties provide for the possibility of derogating from the general prohibition if the disadvantages due to the restraint of competition are largely offset by positive effects which could not be attained by other means within an economy based on free enterprise.

Under the E.C.S.C. Treaty, this waiver operates in favor of specific types of cartels. The High Authority authorizes "agreements to engage in joint buying or selling of specified products," or "agreements strictly analogous in their nature and effects." (E.C.S.C. Treaty art. 65(2).) Under the E.E.C. Treaty, however, which covers a great variety of economic sectors in which very different types of agreement may be found, exemption may be granted in respect of any type of agreement. This more flexible approach allows the granting of exemptions for entire economic sectors. Certain activities might possibly be exempted if, by their nature, they involve very close relations beyond the frontiers, and if, furthermore, the public control to which they are subject in each country excludes all risk of abuse. This particularly could be the case in the insurance and banking business.

${ }^{20}$ E.C.S.C. Treaty art. $65(4)$; E.E.C. Treaty art. $85(2)$. 
Exemption can be granted where the conditions set forth in the Treaties are fulfilled. These conditions are practically identical in both Treaties, with the usual slight difference: more detailed and precise conditions in the E.C.S.C. Treaty, and a broader formulation, easier to adapt to a greater variety of cases, in the E.E.C. Treaty. The agreements must contribute in a positive manner to "an improvement ["substantial" in the E.C.S.C. Treaty] in the production or distribution of the products in question"; the E.E.C. Treaty provides a broader alternative by adding "or to the promotion of technical or economic progress," but subjects these positive elements to an important condition: the agreements must "reserve to users an equitable share in the profit resulting therefrom." It is not sufficient, however, for the agreements to present these advantages. According to the E.C.S.C. Treaty, they must, furthermore, be essential to attain these results, and, according to both Treaties, they must not impose on the enterprises concerned any restrictions greater than necessary for the purpose of the agreement. Finally, a third condition concerns the size and power of the enterprises, and is designed to prevent agreements among enterprises that are too powerful or among too large a number of enterprises.

Although the formulation in the E.C.S.C. Treaty is more precise and detailed, the implementation of these rules can be quite flexible in view of the powers vested in the High Authority. It is alone qualified to decide, without prejudice to the right of appeal to the Court, whether an agreement is or is not subject to article sixtyfive of the E.C.S.C. Treaty. It can authorize an agreement for a limited period and extend it a number of times, or revoke it, if it finds that the agreement no longer fulfills the requisite conditions. Furthermore, the High Authority can make its authorization subject to specified conditions. It thus possesses the means necessary for the progressive adaptation of its policy in the field of cartels to the requirements of the Common Market, with due regard to the interests of the consumers.

The decisions taken under article sixty-five of the E.C.S.C. Treaty must be published in the Journal Officiel by the High Authority with all the grounds on which its decisions are based.

Where the rules regarding cartels and the decisions taken for their implementation are not observed, article sixty-five of the E.C.S.C. Treaty provides for the most severe pecuniary sanctions of the whole Treaty.

In the E.E.C. Treaty, the regulations for implementing articles eighty-five and eighty-six are not yet defined. In an extensive and complex field such as this, in which it is necessary to take into account also the existence of the national laws, it was intended merely to define principles and provide a general framework, while leaving scope for adapting the implementation of the provisions to the special problems experience would reveal.

For this reason, article eighty-seven of the E.E.C. Treaty provides that, at a later stage, appropriate regulations will have to be laid down to ensure compliance with the provisions of articles eighty-five and eighty-six by the institution of pecuniary sanctions, to define the respective responsibilities of the Commisson and of the 
Court of Justice and the relations between national laws and the relevant provisions of the Treaty.

So long as the above-mentioned measures are not taken, two separate bodies are responsible for the implementation of the rules laid down in articles eighty-five and eighty-six of the E.E.C. Treaty. On the one hand, under article eighty-eight, the national authorities can rule on the compatibility of any agreement with the Treaty and upon any improper advantage taken of a dominant position in the Common Market "in accordance with their respective municipal laws" and with the provisions of the E.E.C. Treaty. On the other hand, under article eighty-nine, the Commission has to ensure the application of the principles concerning agreements and abuses of power, investigate any alleged infringement, and propose appropriate means for bringing it to an end. If the proposal is not complied with, the Commission may confirm the existence of the infringement by issuing a reasoned decision and authorize the Member States to take the necessary remedial measures, of which it will determine the conditions and particulars.

The responsibilities thus assigned to the national authorities by article eighty-eight of the E.E.C. Treaty and the fact that the Commission depends on the latter for the investigation of cases of infringement made it necessary that all Member States should appoint the authorities in question. In three countries, however, Belgium, Italy, and Luxembourg, there existed no special laws on competition. The first concern of the Commission was, therefore, to cause such laws to be drawn up in these countries. This was done in Belgium; a bill was also drafted in Italy; and preparations for such a law are in progress in Luxembourg. The laws of the different countries are anything but similar. Since article eighty-eight provides that the authorities must give their opinion "in accordance with their respective municipal law," the risk of arriving at six different interpretations of the rules of the E.E.C. Treaty was very great. To avoid this risk, the Commission called a meeting of representatives of the six national administrations, with the object of jointly working out a uniform interpretation of these rules.

In both Treaties, the problem existed whether the general prohibition on cartels was to come into operation forthwith, making a clean sweep of all the cartels in existence at the time the Treaties came into force, or whether transitional arrangements might not be necessary in order to avoid serious economic disturbances.

The problem was settled in the E.C.S.C. Treaty by section twelve of the Convention containing the Transitional Provisions, which-apart from the measures the High Authority must take in the event of a dissolution of the cartels to protect the interests of the workers and to preserve the productive capacity needed by the Community-stipulates that the High Authority must fix a reasonable time-limit for the coming into effect of the prohibitions laid down in article sixty-five of the E.C.S.C. Treaty. By its Decision No. $37 / 53,{ }^{21}$ the High Authority fixed this limit at August 3I, I953. All cartels that had applied for authorization before this date

22 [1953] JoURNAL OfFICIEL I53. 
were allowed to carry on their activities until a decision was taken by the High Authority in respect of each case. All other cartels were prohibited and declared unlawful.

As regards the E.E.C. Treaty, the Commission, with the support of the six Governments, declared that the rules of competition must be applied from the day the Treaty came into force. The Commission has not, however, taken a decision whether the prohibitions and declarations of invalidity would take effect ex nunc-i.e., only from the day on which the national authorities and the Commission took a decision as to the permissibility, or otherwise, of a cartel-or ex tunc, respectively from the date on which the Treaty came into force. This question will have to be settled by the Court of Justice. The Commission merely wanted to ensure that no powerful cartels would arise and delay the introduction of the Common Market before the rules provided for by article eighty-seven of the E.E.C. Treaty had been laid down.

\section{Concentrations}

The expansion of enterprises by concentration is a particularly characteristic feature of the basic industries, where mass production, technical development, and rationalization call for large production units. Concentrations, however, frequently involve companies that are already very big in themselves, so that concentrations can alter the competitive conditions very suddenly. For this reason, the coal and steel industries are subjected by the E.C.S.C. Treaty to certain rules regarding concentration, while the E.E.C. Treaty, which covers all other economic sectors, contains no provisions to that effect.

While in regard to agreements (cartels) the general principle of the E.C.S.C. Treaty is prohibition (authorization being granted only where advantages in the general interest will result), the reverse is the case where concentrations are concerned: if article sixty-six of the E.C.S.C. Treaty requires prior authorization, it can be refused only when certain conditions are not satisfied.

Any transaction which in itself-i.e., irrespective of the intentions of the parties involved-would have the direct or indirect effect of bringing about a concentration, requires prior authorization, even if the transaction concerns enterprises only one of which falls under the jurisdiction of the E.C.S.C. Treaty.

Like the rules concerning agreements, article sixty-six of the E.C.S.C. Treaty also covers dealers (distributors), but in addition applies to transactions carried out by a person or an enterprise, or a group of persons or enterprises not falling under the E.C.S.C. Treaty. The article does not, however, define what is meant by a group. The High Authority itself will assess, in accordance with the position de facto and de jure, whether several enterprises or persons do or do not form a group within the meaning of this article.

The transaction itself must be carried out within the Community. Article 66(I), of the E.C.S.C. Treaty does not give a definition of a concentration operation, but enumerates the means whereby such a transaction can be carried through-namely, 
"by merger, acquisition of shares or assets, loan, contract or any other means of control." It can thus be seen that the transaction referred to in article sixty-six is the transaction through which a Community enterprise loses its independence (either in relation to other Community enterprises or in relation to enterprises not falling under the Treaty), or a transaction that enables an enterprise of the Community to acquire, within the Common Market, directly or indirectly, the control over enterprises that are not subject to the rules of the E.C.S.C. Treaty.

The intention was to establish control over both horizontal concentrations-i.e., those affecting the size of the enterprises-and vertical concentrations-i.e., those altering the competitive conditions through the acquisition of too powerful a position in regard to sources of supply or markets.

By its Decision No. $24 / 54,{ }^{22}$ the High Authority defined the business relations, financial tie-ups, and interlocking directorships which after taking into account all circumstances, in fact and in law, constitute the control of an enterprise.

For authorization to be granted, it must be shown that the group of enterprises under one and the same control will not occupy a position in the market giving them the power "to determine the prices, to control or restrict production or distribution, or to prevent the maintenance of effective competition in a substantial part of the market or to evade the rules of competition as they result from the execution of the Treaty, in particular by establishing an artificially privileged position involving a substantial advantage in access to supplies or markets."

The conditions laid down in article 66(2) of the E.C.S.C. Treaty do not have to be satisfied merely in relation to the situation prevailing at the time of submitting an application for authorization. The article says clearly: "The High Authority shall grant the authorization ... if it finds that the transaction in question will not give to the interested persons or enterprises . . . the power." Accordingly, the High Authority must take into account the development of the market and the expected increase in production capacities (which it knows from the declarations of investment projects in accordance with article fifty-four), and it must estimate the possible future effects of the concentration in order to determine whether these conditions will still be fulfilled after a reasonable length of time.

It is necessary to ensure a balanced growth of all the Community enterprises, if the Common Market is to operate satisfactorily. The Treaty makes a distinction, however, between internal growth of enterprises, and external growth through concentration. It considers internal growth as the normal and desirable result of the efficiency of the enterprises under the competitive system provided for by the Treaty.

Article sixty-six of the E.C.S.C. Treaty applies only to concentrations carried through after the coming into force of the Treaty and does not affect concentrations that already existed before. This is an essential difference between articles sixty-five and sixty-six, since this distinction is not made in regard to cartels. In assessing the

22 [1954] Journal Officiel 345-46. 
effects of a transaction involving a concentration, the High Authority, therefore, has to take into account the size of enterprises already existing in the Common Market.

As in the case of cartels, the High Authority can make the authorization of a concentration subject to certain conditions. In this respect, however, it does not have the same latitude as in the case of cartels. The conditions must be in line with the criteria laid down in article 66(2), of the E.C.S.C. Treaty. This means that conditions can only be imposed when the High Authority can prove that but for these conditions, the concentration in question could not be authorized at all.

Because of the size and importance of the interests involved in concentration, the authorization, once granted, cannot be altered or revoked. Therein lies a fundamental difference between the rules of the E.C.S.C. Treaty and the antitrust legislation in the United States, where the authorities can step in both before and after a concentration has been effected, without being tied down by time limits. They can thus catch up with a concentration, which the High Authority cannot.

To affect the competitive conditions in the Common Market, a concentration has to be of certain size. This is why, according to article 66(3) of the E.C.S.C. Treaty, the transactions bringing about concentrations of minor importance may be exempted from the requirement of prior authorization. In its Decision No. $25 / 54{ }^{23}$ the High Authority defined the types and size of enterprises for which prior authorization is not required. This exemption is never made in cases of concentrations between producers and dealers, in order to avoid any petrification of the Community's channels of distribution.

Where a concentration has been effected without prior authorization, but, nevertheless, satisfies the conditions of authorization, the High Authority will grant the authorization, but may, in accordance with article 66(5) of the E.C.S.C. Treaty, impose a fine on the parties concerned. If the concentration does not satisfy the conditions, the High Authority is empowered to denounce it as illegal and to order the separation of the enterprises or assets involved. In that case, however, the parties concerned may lodge an appeal with the Court of Justice, which, notwithstanding the provisions of article thirty-three, according to which the Court may not review the High Authority's evaluation of economic facts, has full competence for deciding whether the transaction in question is or is not a concentration within the meaning of article $66(\mathrm{r})$.

\section{Abuses of Power}

The E.C.S.C. Treaty endeavors, as we have seen, to restrain the establishment of dominant positions in the market through concentrations, but it does not abolish the dominant positions that existed before the Common Market was introduced, and it cannot prevent the creation of new dominant positions as a result of the internal growth of the enterprises. The E.E.C. Treaty does not even attempt to restrain concentrations, still less to prevent the creation of dominant positions.

${ }^{23}$ Id. at $346-49$. 
This deficiency in the Treaties can be explained chiefly by the fact that the rules of competition were laid down before the Common Market was actually introduced. The very purpose of a common market is to raise the standard of living, to expand sales outlets, and to increase trade. These objectives imply continued expansion of production and a corresponding growth of the enterprises. It must not be overlooked that European enterprises have remained of a size in keeping with the limitations of their national markets. The Common Market is an attempt to bring about their adaptation to the production conditions of today and in particular to the requirements of a larger market. It is, therefore, understandable that this development was not to be hampered by restrictions where these were not essential to the introduction and operation of the Common Market. This applies particularly to the E.E.C. Treaty, which covers a variety of economic sectors, comprising in many cases new industries in full development. It would have been difficult, and even dangerous, to lay down a rule designed to prevent the acquisition of a dominant position.

Nevertheless, where enterprises occupy or acquire a dominant position, this may present a danger for the Community. These enterprises often have the requisite power to disregard the rules of competition and even act in a manner that prevents or delays the attainment of the objectives of the Communities. In both Treaties, this danger has been warded off by almost identical means-i.e., by granting the institutions the right to put an end to abuses of power.

According to article $66(7)$ of the E.C.S.C. Treaty, where a public or private enterprise has or acquires "a dominant position in the Common Market which protects it from effective competition in a substantial part of this market and this enterprise makes use of such position for purposes contrary to those of the Treaty," the High Authority may put a stop to these practices by means of recommendations. If such recommendations are not carried out, "the High Authority will, after consulting the interested Government, fix the prices and conditions of sale to be applied by the enterprise in question, or draw up a production or delivery program."

In the E.E.C. Treaty, the wording of article eighty-six is more severe and more precise. It forbids the abusive exploitation of a dominant position "to the extent to which it influences trade between member States." These improper practices are enumerated in a non-restrictive manner-namely, direct or indirect imposition of any inequitable trading conditions; limitation of production, markets or technical development to the prejudice of consumers; and discriminatory practices and unfair practices (tying-clauses).

The authority of the various institutions of E.E.C. in regard to the implementation of article eighty-six has not yet been decided, nor have the details of the manner in which these provisions are to be implemented. These will be dealt with in appropriate regulations and directives to be laid down in accordance with article eighty-seven.

Article $66(7)$ of the E.C.S.C. Treaty also mentions "public enterprises." This 
refers particularly to nationalized industries the size of which generally exceeds that of private enterprises, and which may, therefore, easily acquire a dominant position. This does not imply that the other rules of competition do not apply to public enterprises: the rules are applicable to all enterprises, whatever their legal status.

The position in this respect is the same under the E.E.C. Treaty: article ninety, referring to public enterprises, forbids Member States to enact or to maintain in force any measure contrary to the rules contained in the Treaty, in particular to those rules provided for in article seven and in articles eighty-five to ninety-four inclusive.

\section{ConcLusion}

The rules of competition that have been described are not based upon any dogmatic conception of competition. They are one of the main instruments of economic policy for the establishment of the European Common Market and the foundation of the common economic policy to be worked out by the institutions of the Community. However pragmatic the approach to the problems of competition may have been, the rules of competition laid down in the Treaties of Paris and Rome have the merit of having created a new spirit in Europe by preparing public opinion for a competitive system in countries where international and national cartels have been flourishing.

With the object of greater efficiency and greater unity, efforts are in progress for the unification of the institutions set up under the European Treaties. In a first stage, it is to be hoped that the rules of competition, enforced under the E.E.C. and the E.C.S.C. Treaties, will not be affected. They are, indeed, justified in both Treaties by the nature and structure of the industries to which they have to be applied. Rather than an artificial harmonization on political or even legal grounds, the aim should be to take into account economic considerations and to apply the same rules to economic sectors having comparable characteristics. In other words, rules that were deemed necessary for the heavy industries, which by historical accident fall under the E.C.S.C. Treaty, should become applicable also to industries of a similar type that subsequently came under the jurisdiction of the E.E.C. Treaty.

Such transformations involve political choices and are, therefore, outside the province of those entrusted with day-to-day implementation of the rules. The writers would, therefore, merely express the hope that the statesmen responsible for formulating new rules in the field of competition which affects the political freedom and economic welfare of the peoples of Europe will bear in mind that, as Montesquieu wrote in L'Esprit des Lois:

It is sometimes necessary to change certain laws. But this happens rarely; when it does, they must only be touched with a trembling hand; so many solemnities must be observed and so many precautions taken, that the people naturally conclude that the laws are well made, since it requires so many formalities to abrogate them. 